\title{
25 Resarach Soure \\ The Effect of Structural and Environmental Changes on Litter Decomposition of in Pinus Sylvestris Stands
}

Aydın Çömez ( $\square$ acomez@hotmail.com )

Western Black Sea Forestry Research Institute https://orcid.org/0000-0002-1972-0396

Şükrü Teoman Güner

Research Institute For Forest Soil and Ecology

Doğanay Tolunay

Istanbul Universitesi-Cerrahpasa Orman Fakultesi

Research

Keywords: Thinning, Cutting, Organic matter, Litter decay, Forest soil, Scots pine

Posted Date: August 4th, 2020

DOI: https://doi.org/10.21203/rs.3.rs-50741/v1

License: (a) (i) This work is licensed under a Creative Commons Attribution 4.0 International License. Read Full License 


\section{Abstract}

Background: Decomposition of litter has an important role in primary production with its influence on nutrient release for plant uptake and carbon flux in forest ecosystems. Thus, understanding the effects of the intervention on litter decomposition is crucial for sustainable forest management. In this study, the effect of structural change and facing slope on litter decomposition in Scots pine stands (Pinus sylvestris L.) were investigated.

Results: The decomposition rate of litter decreased as the stand age increased. Litter decomposed more rapidly on northern slopes than southern slopes. Cutting caused to accelerate the decomposition at a rate of up to $58 \%$ depending on its intensity. The k values were found to fluctuate though the time from 0.189 in moderately dense canopied stands to 0.317 in open canopied over-mature stands. Stand basal area, incubation time, and remaining carbon concentration of the litter accounted for $75 \%$ of the variation in the decomposition constant.

Conclusions: Cutting-induced stand structural changes affected the litter decomposition process in forest ecosystems due to the micro environmental change as well as the change in litterfall composition and chemistry. Heavy treatments can change the litter decomposition process drastically, while moderate thinning may not have a clear effect in the long run. The stand specific k value should be considered to use in forest carbon models for more accurate estimation. Decomposition constant should be calculated by considering stand structure and incubation time of at least 1050 days. Besides, due to the significant effect of canopy closure on decomposition rate, stand specific or recalculated k constants according to stand basal area, incubation time, and remaining carbon concentration of the litter should be recommended to use in forest carbon models for more accurate carbon budget estimation.

\section{Background}

Plant litter decomposition through microbes and fungi is the only process allowing recycle of chemical elements in forest ecosystems, and thus crucial for sustaining life on earth (Berg and Laskowski 2005). The decomposition of litter is an important process critical to understand the nutrient dynamics as well as the development of nutrient deficiency in a forest ecosystem and responses of the ecosystems to environmental disturbances (Prescott 2010). The most important product of litter decomposition influences soil productivity and microbial biodiversity (Berg and McClaugherty 2014). In the sense of climate change, decomposition of litter has an important role in primary production with its influence on nutrient release for plant uptake and carbon flux (Rodríguez et al. 2009). Organic matter decaying is an important source of carbon dioxide returned to the atmosphere which is the main greenhouse gas with a role in potential global climate change (Berg and McClaugherty 2014).

Silvicultural cutting treatments, that change the structure of stand by reducing canopy cover and basal area, have been applied in forest stands to maintain the growth or to establish a new generation by forest management. Seed cut, a silvicultural harvesting method, which takes all trees but the seed trees, has been widely used for natural regeneration of trees (Youngblood 1991; Schönenberger and Brang 2004) although much of the forests are regenerated by clear-cutting (Dougherty and Duryea 1991). Scots pine stands are commonly regenerated by using the seed cut method in Turkey. As another silvicultural method, thinning has 
been a common silvicultural practice applied in the forest to maintain the growth rate of stands for decades in forestry (Pourmajidian et al. 2010; Tian et al. 2010). All kinds of cutting alter the balance of the ecosystem. Although the effects of thinning on the stand growth, litter production, soil properties, and carbon sequestration were well documented, very few studies were conducted on the thinning effect on litter decomposition dynamics in Pinus sylvestris forests (del Rio et al. 2017). However, contrasting results have been presented by the studies. For example, Blanco et al. (2011) carried out a study in which two degrees of thinning with a control in young Scots pine stands at two different sites, namely the Mediterranean and continental sites, suggesting that decomposition rate decreased with increasing thinning intensity. In contrast, Kunhamu et al. (2009) suggested that high thinning intensities accelerated the decay rate of litter in an Acacia mangium stand. However, Will et al. (1983) reported a non-significant effect of thinning on the decomposition rate of Pinus radiata litter.

The effect of climatic factors such as precipitation, temperature, and evapotranspiration and litter chemistry on litter decomposition was determined by many researchers (Johansson 1994; Sariyildiz 2003; Prescott 2010; Kim 2012). However, less study has been carried out to determine the silvicultural cutting influence on the decomposition rate (Cortina and Vallejo 1994; Kunhamu et al. 2009). On the other hand, litterfall components, including needles, cones, branches, differ in chemical composition and thus have different decomposition patterns (Hristovski et al. 2001; Berg 2014). However, most of the studies on litter decomposition have focused on the foliar litterfall so far. Therefore there is a gap of knowledge on the decomposition of total litterfall.

The objective of this study was to evaluate the effects of stand structure and facing slope on litter decomposition. We hypothesized that mass loss and nutrient release are higher i) in sparse canopy cover than in dense canopy, ii) in young stands than in older, and iii) on the southern slope than on the northern slope.

\section{Methods}

\section{Study Site}

The study was conducted at pure Scots pine stands spreading over Sundiken Mountain range in the inner Anatolia region of Turkey $\left(39^{\circ} 57 \llbracket N, 31^{\circ} 09 \llbracket\right.$ E) on a well-drained luvisol (IUSS Working Group WRB 2015) developed from mica schist, with a sandy loam texture and pH of 5.6-6.0. Sampling was performed in naturally regenerated stands. The study area has a continental climate with low rainfall, with a mean temperature and rainfall of $9.5^{\circ} \mathrm{C}$ and $486 \mathrm{~mm}$, respectively. A detailed description of the study area was given by Çömez et al. (2019).

\section{Sampling procedure}

To cover a wide range of life cycle of the forest and to understand the stand structure effect on litter decomposition, sample plots were chosen from three developmental stages, i.e. young, mature, and overmature stages; and three classes of canopy cover, i.e., open forest $(10-40 \%)$, moderately dense $(40-70 \%)$ and very dense canopy (> 70\%), except young stands because of the lack of open and moderately dense canopied stands, with four replications, 28 in totally (Table 1). To understand the effect of slope aspect on the decomposition rate, two of the replications were established on the northern slope, while the others on the 
southern slope. Mature and over-mature stands studied were exposed silvicultural treatments 5 to 8 years before the measurements by the local authority. Litterfall samples were collected by $0.5 \times 0.5 \mathrm{~m}$ traps for two years to attain enough amounts of litterfall samples to be placed in litter bags. After having collected the samples in each sample plot, litter samples with an air-dried weight of approximately $10 \mathrm{~g}$ including needles, bark, branches, and cones, taking into account their share in the total litterfall were filled into the litter bags to determine the overall litter decomposition. The shares of litterfall components are given in Table 1. To determine the litter decomposition rate, 60 litter bags, made from nylon nets with $1 \times 1 \mathrm{~mm}$ mesh and $20 \times$ $15 \mathrm{~cm}$ in size, were filled with litter and placed on the ground of each sample plot. Four litter bag samples were collected from each plot every two to five months for four years. The mean mass loss rate was calculated from the four litter bags of each plot.

Table 1

Some attributes litterfall fractions of the stands studied $(n=4)$

\begin{tabular}{|c|c|c|c|c|c|c|c|c|c|c|}
\hline $\begin{array}{l}\text { Stand } \\
\text { structure }\end{array}$ & Age & $\begin{array}{l}\text { Dbh } \\
\text { (cm) }\end{array}$ & $\begin{array}{l}\text { Mean } \\
\text { Height } \\
\text { (m) }\end{array}$ & $\begin{array}{l}\text { Density } \\
\text { (Tree } \\
\mathrm{ha}^{-1} \text { ) }\end{array}$ & $\begin{array}{l}\text { Basal } \\
\text { Area } \\
\left(\mathrm{m}^{2}\right. \\
\left.\mathrm{ha}^{-1}\right)\end{array}$ & $\begin{array}{l}\text { Needles } \\
\text { (\%) }\end{array}$ & $\begin{array}{l}\text { Bark } \\
(\%)\end{array}$ & $\begin{array}{l}\text { Branches } \\
\text { (\%) }\end{array}$ & $\begin{array}{l}\text { Cones } \\
\text { (\%) }\end{array}$ & $\begin{array}{l}\text { Misc. } \\
\text { (\%) }\end{array}$ \\
\hline Young & 15 & 4 & 2 & 8700 & 7 & 87 & 2 & 3 & 3 & 6 \\
\hline $\begin{array}{l}\text { Mature } \\
\text { open }\end{array}$ & 93 & 31 & 17 & 200 & 15 & 40 & 8 & 5 & 41 & 7 \\
\hline $\begin{array}{l}\text { Mature } \\
\text { moderately } \\
\text { dense }\end{array}$ & 98 & 29 & 19 & 500 & 33 & 58 & 10 & 6 & 19 & 9 \\
\hline $\begin{array}{l}\text { Mature } \\
\text { dense }\end{array}$ & 100 & 29 & 20 & 688 & 45 & 55 & 10 & 10 & 15 & 10 \\
\hline $\begin{array}{l}\text { Over- } \\
\text { mature } \\
\text { open }\end{array}$ & 117 & 43 & 22 & 119 & 18 & 43 & 8 & 13 & 26 & 11 \\
\hline $\begin{array}{l}\text { Over- } \\
\text { mature } \\
\text { moderately } \\
\text { dense }\end{array}$ & 127 & 45 & 24 & 238 & 37 & 47 & 10 & 15 & 14 & 16 \\
\hline $\begin{array}{l}\text { Over- } \\
\text { mature } \\
\text { dense }\end{array}$ & 110 & 38 & 24 & 400 & 45 & 50 & 10 & 14 & 15 & 11 \\
\hline
\end{tabular}

\section{Laboratory methods}

Litter bag samples were oven-dried at $70^{\circ} \mathrm{C}$ until constant weight before the weighting. Mass loss was calculated by Eq. (1):

$$
M_{R}=\frac{M_{0}-M_{t}}{M_{0}} \times 100
$$


Where $M_{R}$ is remaining mass (\%), $M_{0}$ is the initial mass of litter $(g), M_{t}$ is the litter mass $t$ time later $(g)$

Accumulated carbon (C) and nitrogen (N) release were calculated by Eq. (2):

$$
C, N_{r}=M_{R} \times C, N_{\text {Conc. }}
$$

2

Where $C, N_{r}$ is accumulated carbon or nitrogen release (\%), $M_{R}$ is the remaining litter mass (\%), $C, N_{\text {Conc }}$. is the carbon or nitrogen concentration of the decomposing litter (\%), respectively.

Decomposition constant was calculated by Olson (1963), Eq. (3):

$$
k=-\log \frac{M_{t}}{M_{0}}
$$

3

Where $k$ is decomposition constant, $M_{0}$ is the initial mass of litter $(g), M_{t}$ is the litter mass $t$ time later $(g)$

The samples were analyzed for carbon and nitrogen by the Dumas method using the LECO CNH analyzer (Leco Corporation, St. Joseph, Michigan). Nitrogen and carbon concentrations were standardized to initial concentrations by multiplying their concentrations by remaining mass percent.

\section{Statistical analysis}

Data was controlled by the Shapiro-Wilk test for the normal distribution, while the homogeneity of variance by Levene's test. When data normally distributed, variations in the mass loss by time and stand type evaluated by Repeated Measure ANOVA, taking the maturity, canopy, and facing slopes as between-subject factors. All data showed normal distribution and homogeneous variance. The Scheffe test was used to determine the homogenous groups.

Decomposition constant was estimated by multiple regression analysis, using the basal area of the stands $\mathrm{m}^{2}$ $\mathrm{ha}^{-1}$ ), stand age (year), the length of the incubation period of the litter (days), and accumulated $\mathrm{C}$ and $\mathrm{N}$ concentration (\%) as independent variables. Equations with the highest $\mathrm{R}^{2}$, the lowest standard error, and constants with a significant level at $\mathrm{P}<0.05$ were given in this study.

\section{Results}

\section{Litter Mass Loss}

The remaining mass of the litter and $\mathrm{k}$ constant varied significantly with time and stand canopy, as well as slope facing. Interactions between the time and stand canopy affected the litter decomposition. Canopy closure and slope facing also affected significantly decomposition dynamics (Table 2). 
Table 2

Repeated measures ANOVA results for the differences in remaining mass and $\mathrm{k}$ value

\begin{tabular}{|lllll|}
\hline & Remaining mass & \multicolumn{3}{c|}{ k value } \\
\hline & $F$-value & $p$-value & $F$-value & $p$-value \\
\hline Within subject effects & & & & \\
\hline Time & 504.520 & $<0.0001$ & 12.043 & $<0.0001$ \\
\hline Time $\times$ maturity & 0.376 & 0.727 & 0.597 & 0.594 \\
\hline Time $\times$ canopy & 3.418 & 0.014 & 1.544 & 0.201 \\
\hline Time $\times$ slope facing & 1.209 & 0.317 & 0.289 & 0.800 \\
\hline Time $\times$ slope facing $\times$ maturity $\times$ canopy & 1.684 & 0.167 & 0.646 & 0.668 \\
\hline Between subject effects & & & & \\
\hline Maturity & 0.050 & 0.826 & 0.052 & 0.823 \\
\hline Canopy & 4.477 & 0.031 & 3.191 & 0.072 \\
\hline Slope facing & 7.035 & 0.019 & 7.432 & 0.016 \\
\hline Maturity $\times$ canopy $\times$ slope facing & 4.912 & 0.024 & 4.109 & 0.039 \\
\hline
\end{tabular}

At the end of the incubation time of 1367 days, $30 \%$ of the initial litter mass was remained undecomposed in young stands, while that of almost half in moderately dense and dense ones. Although the remaining mass was higher in the moderately dense forest in mature stands, it was low in dense over-mature stands. Open canopied stands had a lower remaining mass in both mature and over-mature ones. As the canopy became more open, the remaining mass of the litter decreased, except for moderately dense mature stands. An ascending trend was observed in stands from young to over-mature stage in remaining litter mass, from $30 \%$ in young stands to $49 \%$ in over-mature stands. Decomposition constant was found to be highest in young stands while the lowest in moderately dense mature stands with an increasing tendency from the dense canopy to open and young forest, with the exception of moderately dense mature stands (Table 3). 
Table 3

Remaining mass at the end of the study period and overall decomposition constant $(k)$

\begin{tabular}{|lll|}
\hline Stand structure & $\begin{array}{l}\text { Remaining mass } \\
\text { (\%) }\end{array}$ & k value \\
\hline Young & $30.09 \pm 3.08 \mathrm{a}$ & $0.349 \pm 0.032 \mathrm{c}$ \\
\hline Open mature & $41.01 \pm 3.88 \mathrm{abc}$ & $0.256 \pm 0.032 \mathrm{ab}$ \\
\hline Moderately dense mature & $49.32 \pm 1.82 \mathrm{c}$ & $0.189 \pm 0.010 \mathrm{a}$ \\
\hline Dense mature & $45.38 \pm 4.17 \mathrm{bc}$ & $0.215 \pm 0.025 \mathrm{a}$ \\
\hline Open over-mature & $34.16 \pm 4.89 \mathrm{ab}$ & $0.317 \pm 0.046 \mathrm{bc}$ \\
\hline Moderately dense over-mature & $42.17 \pm 4.35 \mathrm{abc}$ & $0.235 \pm 0.027 \mathrm{ab}$ \\
\hline Dense over-mature & $49.37 \pm 3.96 \mathrm{c}$ & $0.201 \pm 0.022 \mathrm{a}$ \\
\hline F-value & 3.628 & 4.207 \\
\hline$p$-value & 0.013 & 0.006 \\
\hline Same letters in the same column donate the same groups \\
\hline
\end{tabular}

Remaining masses of the litter were found to be very close to each other between northern and southern slopes in young stands, while those of northern slopes were lower than southern ones in both mature and over-mature stands. Litter was decomposed more in open canopied stands than in both moderately dense and dense canopied ones, except in mature stands on the northern slope. The decomposition process occurred more rapidly on the northern slopes (Fig. 1).

Decomposition constant showed an increase towards to end of the first year in all stands, with the highest in young and the lowest in over-mature dense-canopied stands. After the third year of the incubation, $\mathrm{k}$ constants of the moderately dense and dense stands have remained steady, while those of young and over-mature open forests have continued to increase slightly. Differences in $\mathrm{k}$ constant between open and moderately dense canopied forests became pronounced after 687 days of incubation (Fig. 2).

Stand basal area alone accounted for $47 \%$ of the variation in k constant that calculated for 1367 days, while for $75 \%$ of that along with incubation days and remaining $\mathrm{C}$. Basal area, incubation days, and remaining $\mathrm{C}$ in the litter were negatively related to $k$ constant (Table 4). 
Table 4

Multiple linear regression models based on basal area and elevation to predict the k constant

\begin{tabular}{|llllll|}
\hline Model & $\mathbf{R}^{2}$ & SEE & & Coefficient & $\boldsymbol{p}$ \\
\hline 1 & 0.469 & 0.057 & Constant & $0.323 \pm 0.007$ & $<0.0001$ \\
& & & Basal area & $-0.002 \pm 0.0002$ & $<0.0001$ \\
\hline 3 & 0.754 & 0.034 & Constant & $0.923 \pm 0.024$ & $<0.0001$ \\
& & & Basal area & $-0.000376 \pm 0.000154$ & 0.015 \\
& & & Days & $-0.000288 \pm 0.000012$ & $<0.0001$ \\
& & & Remaining C & $-0.0138 \pm 0.000567$ & $<0.0001$ \\
\hline
\end{tabular}

\section{Carbon and nitrogen mineralization}

The initial nitrogen concentration of the litter was ranged from $0.92 \%$ in dense canopied stands to $1.24 \%$ in young stands, with a significant difference $(P<0.01)$ between young stands and the other stands. However, there was no significant difference at the end of the 155 days, with a decline of 0.42 to $0.49 \%$ of $\mathrm{N}$ concentration. An increasing trend in N concentrations of the litter was observed after the 155 days of incubation, with the effect of treatment and time. Accumulated $\mathrm{N}$ was considerably decreased from 1.24$0.92 \%$ to $0.37-0.44 \%$ through the time and stabilized around $0.45 \%$ between the incubation days of 524 and 1137. Subsequently, a slight decrease trend was observed after 1137 days (Fig. 3a-b).

Carbon concentrations of the litter fluctuated from $50-55 \%$ through the study period, with a significant difference $(P<0.01)$ according to repeated measures of ANOVA. Initial carbon concentrations among the stands were not significantly different, ranging from 51 to $54 \%$. Cumulative carbon concentrations showed a steady decrease from 53-21\%, approximately. At the end of 1367 days of incubation, $24 \%$ of the initial carbon remained undecomposed in the dense stands, while that of $15 \%$ in young stands (Fig. 3c-d).

Initial N concentrations of the litters were significantly different among the stands, with the highest in young stands and the lowest in dense stands $(P<0.01)$. An increase in the $N$ concentrations from dense stands to the open-canopied as well as the young ones was observed. However, there were no significant differences in initial carbon concentrations among the stands, although litter from dense stands had the highest carbon concentration with a mean of $54 \%$ and the moderately dense stands had the lowest with $51 \%$ (Table 5). 
Table 5

\begin{tabular}{|c|c|c|}
\hline Stands & $\mathbf{N}$ & C \\
\hline Young & $1.235 \pm 0.021 b$ & $53.273 \pm 0.977 a$ \\
\hline Open-canopied & $1.054 \pm 0.039 a$ & $53.308 \pm 0.552 a$ \\
\hline Moderately dense & $0.948 \pm 0.048 a$ & $51.046 \pm 2.140 a$ \\
\hline Dense & $0.920 \pm 0.051 \mathrm{a}$ & $54.114 \pm 0.658 a$ \\
\hline $\mathrm{F}$ & 6.814 & 1.149 \\
\hline$P$ & 0.002 & 0.350 \\
\hline
\end{tabular}

Remaining litter mass was correlated with the initial $N$ concentration at a significance level of $P<0.01$. The remaining mass decreased with increasing $\mathrm{N}$ concentration of the litterfall (Fig. 4).

\section{Discussion}

\section{Litter decomposition}

The decomposition of forest litter is a process mainly driven by environmental conditions and the quality of the substrate (Sariyildiz and Kucuk 2008; Berg and McClaugherty 2014; Karishna and Mohan 2017). Silvicultural treatments, such as thinning and seed cutting, can alter environmental conditions as well as production (Prescott et al. 2004; Tian et al. 2010) and composition of litterfall. Besides, the quantity and quality of the forest floor can be changed by residues left in the stand after the cutting treatments. In our study, lower remaining litter mass in young and open canopied forests compared to dense ones indicated that stand structure influenced on the decomposition rate of the forest floor by changing the environmental conditions, namely temperature and moisture in the stands. Besides, thinning operations can affect litterfall composition as suggested by Blanco et al. (2006). Specifically, needle litter was more dominant in young stands, leading to a high decomposition rate due to easily decomposable chemical composition. Cutting in forest results in a decrease of canopy closure and the basal area left, leading to more rainfall and light to reach the soil surface (Prescott et al. 2004; Tian et al. 2010). Thus, the activity of decomposers accelerates, and consequently decomposition rate of the litter increases. Despite low needle litterfall, an easily decomposable fraction due to low lignin and high nitrogen content, but a higher cones fraction, decomposition rates were higher in the open canopied stands, likely due to the prevailing effect of microclimatic condition on soil biota. Unlike the needles, cones have a woody structure, indicating that they include more lignin than needles do (Taylor et al. 1991; Font et al. 2009). High lignin content causes a slow break down in the forest floor (Sariyildiz and Kucuk 2008; Wang et al. 2018). Our results clearly showed that cuttings accelerated the decomposition of litter in a mature stand, meaning an increased carbon emission.

The remaining mass of litter in young stands which had a needle fraction of $87 \%$ of the total litterfall was close to some studies regarding needle litter decomposition (Berg and Staaf 1980; Laiho et al. 2004), likely due to similar climatic conditions and a high needles fraction of our study. On the other hand, Sariyildiz and Kucuk (2008) reported a higher decomposition rate compared to our results, likely because their results were for 
needle litterfall. Pausas (1997) reported that the k values varied between 0.221 and 0.283 for Scots pine stands, which were close to our results for moderately dense and open canopied forests but lower for young and higher for dense ones. An additional explanation may be the suitable climate of their study area with more moist conditions. On the other hand, Sariyildiz (2008) observed a closer decomposition rate to our results for young stand stands, with $\mathrm{k}$ values from 0.3 to 0.4 . Janušauskaité et al. (2013) reported a lower decomposition rate for northern sites. This may be related to the retarding effect of low temperature on decomposition (Berg 2014; Krishna and Mohan 2017). Enez et al. (2015) found a lower decomposition rate of needle litter on scalped mineral soil than on non-harvesting activity areas under Scots pine stand due to the less microbial activity. Thus, litter decomposition dynamics of young stand might differ from those of mature ones due to the differences in composition of the litterfall and the changes in environmental conditions of the stands.

Many researchers reported that the slope facing affected decomposition rate with the faster on the northern slope than on the southern slope (Sariyildiz and Kucuk 2008; Jasińska et al. 2019). On the other hand, some researchers reported a faster decomposition of litterfall on the south aspects than on the north (Mudrick et al. 1994; Qualls 2016), which was in line with our results. Furthermore, in open canopied mature stands, decomposition rate was found to be faster on southern slopes in comparison to the north in contrast to in the case of the dense canopy, likely due to age- and light-related changes in litterfall composition.

We did not determine the decomposition rates of the litter fractions separately in our study since all litterfall fractions make up the forest floor and decompose together. To take into account only a certain fraction of litterfall such as needles or leaves could result in an overestimation of litter decomposition rate.

\section{Temporal changes in $\mathrm{k}$ constant and estimation models}

Decomposition constant trends showed different patterns due to changes in the chemical composition of litter and microbial diversity during decomposition process (Yue et al. 2018), indicating that $k$ constant would be stabilized after approximately 1000 days in dense and moderately dense forest, while not in open as well as young stands. In addition, $\mathrm{k}$ constant might continue to increase slightly until 1400 days in open-canopied and young stands. Therefore, $\mathrm{k}$ values might be underestimated in young stands, as well as heavily thinned stands, in case of incubation time shorter than 1400 days. Our results partly confirmed the Berg et al. (2010), who proposed that 1100 to 2000 days of the period were sufficient for limit values of litter decomposition. Still, there is a need for further studies on the decomposition rate in young and mature stands with heavily treated.

Basal area is an important parameter that can be used for evaluating the stand structure and decreased by silvicultural interventions as well as natural or human-induced disturbances. A decline in the basal area, meaning also a decrease in canopy cover, leads to more sunlight and rainfall to reach the forest floor, favoring the environmental conditions for microbial activity. Therefore, the basal area gave a robust fit with $\mathrm{k}$ constant.

\section{Nitrogen and carbon releasing}

Our results showed that initial $\mathrm{N}$ concentrations of litter were related to the decomposition rate. Higher $\mathrm{N}$ concentrations in young stands also supported this relationship. An increase in the $\mathrm{N}$ concentration causes to 
decrease in C: $\mathrm{N}$ ratio, which is an index for litter decomposition. Sun et al. (2016) also reported a decreasing trend in $\mathrm{N}$ concentration of senesced pine needles from young to older stands. The decreasing trend in $\mathrm{N}$ with stand age might be related to changes in soil nutrient availability and forest growth rates during stand development, as pointed out by Sun et al. (2016). Besides, the concentrations tended to increase slightly with the canopy structure of the stands became more open, indicating that cuttings might result in changes in nutrient withdrawal before needle shed in pines in contrast to Blanco et al. (2009) reported. But our results confirm the findings of Berg et al. (1995), who reported that $\mathrm{N}$ concentration in needle litter of Scots pine was mainly related to climatic conditions. On the other hand, the initial $\mathrm{N}$ concentration of the litter for the dense forests of our study was similar to the results of Blanco et al. (2006) for needle litter of Scots pine stands in sites with a cold wet Mediterranean climate. However, they reported lower values for sites with a cold wet continental climate than our results. They also suggested that thinning affected $\mathrm{N}$ concentration of needle litter.

In this study, higher initial $\mathrm{N}$ concentration of litter resulted in a higher decomposition rate as revealed by many researchers (Gao et al. 2019; Sariyildiz 2003; Zhang et al. 2008) in contrast to Berg (2000). The enhancing effects of $\mathrm{N}$ on decomposition rate may be related to rich microbial diversity supported by the high nutritious value of the litter (Gao et al. 2015), which has a high proportion of needles that contains higher nutrients compared to other litter fractions in young stands. On the other hand, despite the lower nutrient content likely due to the inclusion of a higher portion of fine woody litter, the decomposition rate in open-canopied stands also was higher than in the moderately thinned and un-thinned stands likely because of the prominent effects of temperature and humidity on the decomposition process.

\section{Conclusions}

In this study, it was concluded that cutting-induced stand structure change affected the litter decomposition process in forest ecosystems due to the micro environmental change as well as the change in litterfall composition and chemistry. Although moderate thinning could not change the litter decomposition process drastically, heavy treatments could do in the long run. Relatively higher precipitation reaching the forest floor with together temperature due to the decreasing of canopy might cause a rapid $\mathrm{N}$ mineralization, thus, leading to needle fall with reach in $\mathrm{N}$ concentration. However, there is a need for further researches on the effect of thinning on the nutrient re-translocation process. On the other hand, it is important to use decomposition constant which relies on long term incubation, with at least 1050 days. Besides, due to the significant effect of canopy closure on decomposition rate, stand specific or recalculated k constants according to stand basal area should be recommended to use in forest carbon models for more accurate carbon budget estimation.

\section{Abbreviations}

$\mathrm{N}$ : nitrogen; C: carbon; $\mathrm{k}$ : litter decomposition constant; $\mathrm{R}^{2}$ : coefficient of determination; SEE: standard error of the estimation

\section{Declarations}

\section{Acknowledgements}


We thank our colleague Rıza Karataş (MSc) for his help during the fieldwork and data collection.

\section{Authors' contributions}

ÇA, GŞT, and TD conceived the ideas and designed methodology; ÇA and GŞT collected the data; ÇA analyzed carbon and nitrogen concentrations; ÇA and GŞT analyzed the data; AÇ led the writing of the manuscript. All authors contributed critically to the drafts and gave final approval for publication.

\section{Funding}

The study was funded by Turkish General Directorate of Forestry in a framework of a research project (Project No: ESK-09 (6303)/2010-2016).

\section{Availability of data and materials}

The datasets and materials used during the present study were obtained from the field and laboratory by the authors and are available from the corresponding author on reasonable request.

\section{Ethics approval and consent to participate}

Not applicable.

\section{Consent for publication}

Not applicable.

\section{Competing interests}

The authors declare that they have no competing interests.

\section{References}

1. Berg B (2000) Litter decomposition and organic matter turnover in northern forest soils. For Ecol Manag 133: 13-22. doi: 10.1016/S0378-1127(99)00294-7.

2. Berg B (2014) Foliar Litter Decomposition: A Conceptual Model with Focus on Pine (Pinus) Litter-A Genus with Global Distribution. ISRN Forestry Volume 2014 Article ID 838169, 22 pages. doi: $10.1155 / 2014 / 838169$.

3. Berg B, Staaf H (1980) Decomposition rate and chemical changes of scots pine needle litter. I-Influence of stand age. Ecoll Bull 32: 363-372.

4. Berg B, Calvo de Anta R, Escudero A, Gärdenäs A, Johansson MB, Laskowski R, Madeira M, Mälkönen E, McClaugherty C, Meentemeyer M, Virzo De Santo A (1995) The chemical composition of newly shed needle litter of Scots pine and some other pine species in a climatic transect. X Long-term decomposition in a Scots pine forest. Can J Bot 73: 1423-1435.

5. Berg B, Laskowski R (2005) Litter Decomposition: A Guide to carbon and Nutrient Turnover. Academic Press, USA. 
6. Berg B, Davey MP, De Marco A, Emmett B, Faituri M, Hobbie SE, Johansson MB, Liu C, McClaugherty C, Norell L, Rutigliano FA, Vesterdal L, Virzo De Santo A (2010) Factors influencing limit values for pine needle litter decomposition: a synthesis for boreal and temperate pine forest systems. Biogeochemistry 100:57-73. doi: 10.1007/s10533-009-9404-y.

7. Berg B, McClaugherty C (2014) Plant Litter-Decomposition, Humus Formation, Carbon Sequestration. Springer-Verlag, Berlin.

8. Blanco JA, Imbert JB, Castillo FJ (2006) Nutrient return via litterfall in two contrasting Pinus sylvestris forests in the Pyrenees under different thinning intensities. For Ecol Manage 256: 1840-1852. doi: 10.1016/j.foreco.2008.07.011.

9. Blanco JA, Imbert JB, Castillo FJ (2009) Thinning affects nutrient resorption and nutrient-use efficiency in two Pinus sylvestris stands in the Pyrenees. Ecol Appl 19(3): 682-698. doi: 10.1890/1051-0761-19.3.682.

10. Blanco JA, Imbert JB, Castillo FJ (2011) Thinning affects Pinus sy/vestris needle decomposition rates and chemistry differently depending on site conditions. Biogeochemistry 106: 397-414. doi: 10.1007/s10533010-9518-2.

11. Cortina J, Vallejo VR (1994) Effects of clearfelling on forest floor accumulation and litter decomposition in a radiate pine plantation. For Ecol Manag 70: 299-310. doi: 10.1016/0378-1127(94)90095-7.

12. Çömez A, Tolunay D, Güner ŞT (2019) Litterfall and the effects of thinning and seed cutting on carbon input into the soil in Scots pine stands in Turkey. Eur J Forest Res 138: 1-14. doi: 10.1007/s10342-0181148-6.

13. del Río M, Bravo-Oviedo A, Pretzsch H, Löf M, Ruiz-Peinado R (2017) A review of thinning effects on Scots pine stands: From growth and yield to new challenges under global change. Forest Syst 26 (2), eR03S, 19 pages. doi: 10.5424/fs/2017262-11325.

14. Dougherty PM, Duryea ML (1991) Regeneration: An Overview of Past Trends and Basic Steps Needed to Ensure Future Success. In: Duryea M, Daugherty PM (eds) Forest Regeneration Manual. Springer- Science+Business Media, B.V., USA.

15. Enez K, Aricak B, Sariyildiz T (2015) Effects of harvesting activities on litter decomposition rates of Scots pine, Trojan fir, and sweet chestnut. Šumarski List 139: 361-368.

16. Font R, Conesa JA, Moltó J, Muñoz M (2009) Kinetics of pyrolysis and combustion of pine needles and cones. J Anal Appl Pyrolysis 85: 276-286. doi: 10.1016/j.jaap.2008.11.015.

17. Gao J, Kang F, Li T, Song X, Zhao W, Yu X, Han H (2015) Assessing the Effect of Leaf Litter Diversity on the Decomposition and Associated Diversity of Fungal Assemblages. Forests 6: 2371-2386. doi: 10.3390/f6072371.

18. Gao J, Han H, Kang F (2019) Factors controlling decomposition rates of needle litter across a chronosequence of Chinese pine (Pinus tabuliformis Carr.) forests. Pol J Environ Stud 28(1): 91-102. doi: $10.15244 /$ pjoes/84770.

19. Hristovski S, Melovski LJ, Grupche LJ, Šušlevska M (2001) Litter decomposition rate of leaves, branches and beech acorns in the beech ecosystem calamintho grandiflorae-fagetum in 'Mavrovo' national park. In: Radoglou K (ed) Proceedings of the International Conference: Forest research: a challenge for an integrated European approach, Thessaloniki, 1999. 
20. IUSS Working Group WRB, 2015. World reference base for soil resources 2014, update 2015. International soil classification system for naming soils and creating legends for soil maps. World Soil Resources Reports No. 106. FAO, Rome.

21. Janušauskaitė D, Baliuckas V, Dabkevičius Z (2013) Needle litter decomposition of native Pinus sy/vestris L. and alien Pinus mugo at different ages affecting enzyme activities and soil properties on dune sands. Baltic For 19(1): 50-60.

22. Jasińska J, Sewerniak P, Markiewicz M (2019) Links between slope aspect and rate of litter decomposition on inland dunes. Catena, 172: 501-508. doi: 10.1016/j.catena.2018.09.025.

23. Karishna MP, Mohan M (2017) Litter decomposition in forest ecosystems: a review. Energ Ecol Environ 2(4): 236-249, doi: 10.1007/s40974-017-0064-9.

24. Kunhamu TK, Kumar BM, Viswanath S (2009) Does thinning affect litterfall, litter decomposition, and associated nutrient release in Acacia mangium stands of Kerala in Peninsular India? Can J For Res 37: 792-801. doi: 10.1139/X09-008.

25. Laiho R, Laine J, Trettin CC, Finér L (2004) Scots pine litter decomposition along drainage succession and soil nutrient gradients in peatland forests, and the effects of inter-annual weather variation. Soil Biol Biochem 36: 1095-1 109. doi: 10.1016/j.soilbio.2004.02.020.

26. Mudrick DA, Hoosein M, Hicks Jr RR, Townsend EC (1994) Decomposition of leaf litter in an Appalachian forest: effects of leaf species, aspect, slope position and time. For Ecol Manag 68: 231-250. doi: /10.1016/0378-1127(94)90048-5.

27. Olson JS (1963) Energy storage and balance of producers and decomposers in ecological systems. Ecology 44: 1-36. doi: 10.2307/1932179.

28. Pausas JG (1997) Litter fall and litter decomposition in Pinus sy/vestris forests of the eastern Pyrenees. J Veget Sci 8: 643-650. doi: 10.2307/3237368.

29. Pourmajidian MR, Jalilvand H, Fallah A, Hosseini SA, Parsakhoo A, Vosoughian A, Rahmani A (2010) Effect of shelterwood cutting method on forest regeneration and stand structure in a Hyrcanian forest ecosystem. J Forest Res 21(3): 265-272. doi: 10.1007/s11676-010-0070-7.

30. Prescott CE (2010) Litter decomposition: what controls it and how can we alter it to sequester more carbon in forest soils? Biogeochemistry 101:133-149. doi: 10.1007/s10533-010-9439-0.

31. Prescott, C.E., L.L. Blevins, and C. Staley. 2004. Litter decomposition in British Columbia forests: Controlling factors and influences of forestry activities. BC J Ecosyst Manag 5(2):44- 57.

32. Qualls RG (2016) Long-Term (13 Years) Decomposition rates of forest floor organic matter on paired coniferous and deciduous watersheds with contrasting temperature regimes. Forests 7(231): 1-17. doi: 10.3390/f7100231.

33. Rodríguez PCR, Durán ZVH, Muriel FJL, Martín PFJ, Franco TD (2009) Litter decomposition and nitrogen release in a sloping Mediterranean subtropical agroecosystem on the coast of Granada (SE, Spain): Effects of floristic and topographic alteration on the slope. Agr Ecosyst Environ 134: 79-88. doi: 10.1016/j.agee.2009.05.019.

34. Sariyildiz T (2003) Litter decomposition of Picea orientalis, Pinus sylvestris and Castanea sativa trees grown in Artvin in relation to their initial litter quality variables. Turk J Agric For 27: 237-243. 
35. Sariyildiz T (2008) Effects of tree canopy on litter decomposition rates of Abies nordmanniana, Picea orientalis and Pinus sy/vestris. Scand J For Res, 23: 330-338. doi: 10.1080/02827580802275816.

36. Sariyildiz T, Kucuk M (2008) Litter Mass Loss Rates in Deciduous and Coniferous Trees in Artvin, Northeast Turkey: Relationships with Litter Quality, Microclimate, and Soil Characteristics. Turk J Agric For 32: 547-559.

37. Schönenberger W, Brang P (2004) Silviculture in Mountain Forests. In: Burley J, Evans J, Youngquist JA. (eds) Encyclopedia of Forest Science. Academic Press, London.

38. Sun Z, Liu L, Peng S, Peñuelas J, Zeng H, Piao S (2016) Age-Related Modulation of the Nitrogen Resorption Efficiency Response to Growth Requirements and Soil Nitrogen Availability in a Temperate Pine Plantation. Ecosystems 19(4). doi: 10.1007/s10021-016-9962-5.

39. Taylor BR, Prescott CE, Parsons PWJ, Parkinson D (1991) Substrate control of litter decomposition in four Rocky Mountain coniferous forests. Can. J. Bot. 69: 2242-2250. doi: 10.1139/b91-281.

40. Tian DL, Peng YY, Yan WD, Fang X, Kang WX, Wang GJ, Chen XY (2010) Effects of thinning and litter fall removal on fine root production and soil organic carbon content in Masson pine plantations. Pedosphere 20(4): 486-493. doi: 10.1016/S1002-0160(10)60038-0.

41. Wang W, Page-Dumroese D, Jurgensen M, Tirocke J, Liu Y (2018) Effect of forest thinning and wood quality on the short-term wood decomposition rate in a Pinus tabuliformis plantation. J Plant Res. doi: 10.1007/s10265-018-1069-y.

42. Will GM, Hodgkiss PD, Madgwick Al (1983) Nutrient losses from litterbags containing Pinus radiata litter: Influences of thinning, clearfelling, and urea fertilizer. NZ J Forestry Sci 13(3): 291-304.

43. Youngblood AP (1991) Radial growth after a shelterwood seed cut in a mature stand of white spruce in interior Alaska. Can J For Res 21: 410-413. doi: 10.1139/x91-052.

44. Yue K, García-Palacios P, Parsons SA, Yang W, Peng Y, Tan B, Huang C, Wu F (2018) Assessing the temporal dynamics of aquatic and terrestrial litter decomposition in an alpine forest. Funct Ecol, 1-12. doi: 10.1111/1365-2435.13143.

45. Zhang D, Hui D, Luo Y, Zhou G (2008) Rates of litter decomposition in terrestrial ecosystems: global patterns and controlling factors. J Plant Ecol 1(2): 85-93. doi: 10.1093/jpe/rtn002.

\section{Figures}




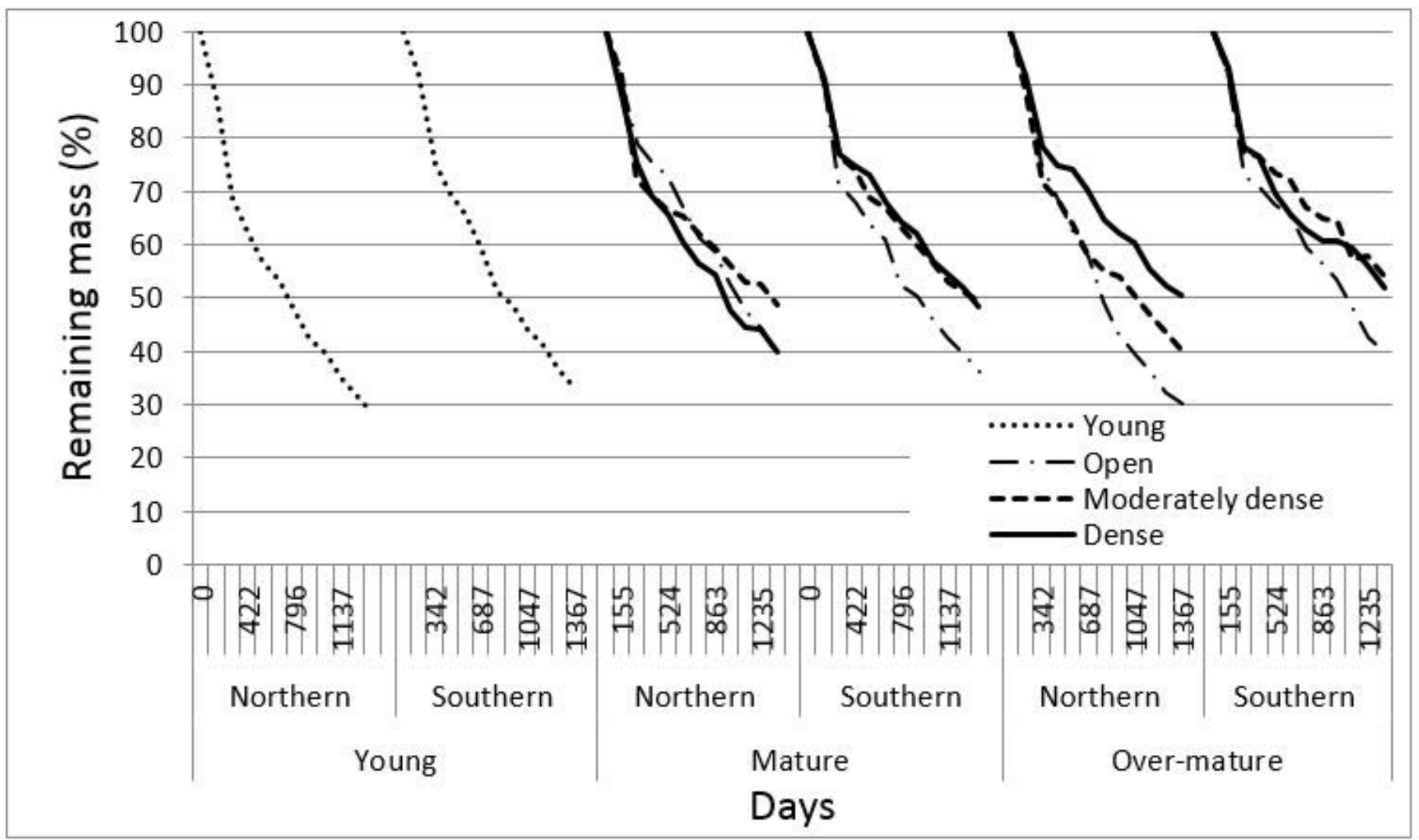

Figure 1

Changes in remaining mass of the litter with facing slopes, stand development, and cano 


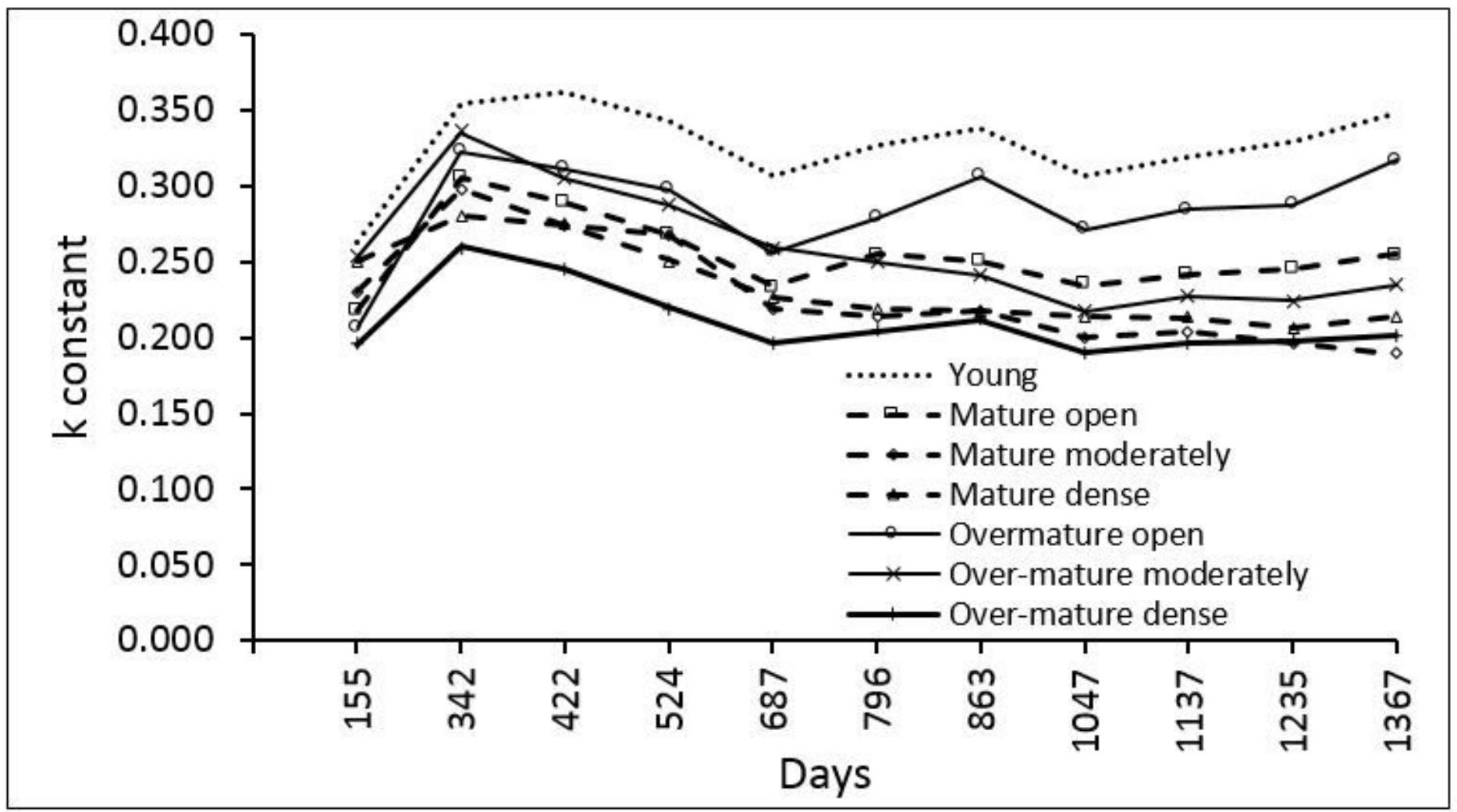

Figure 2

The course of $k$ values according to sampling periods 

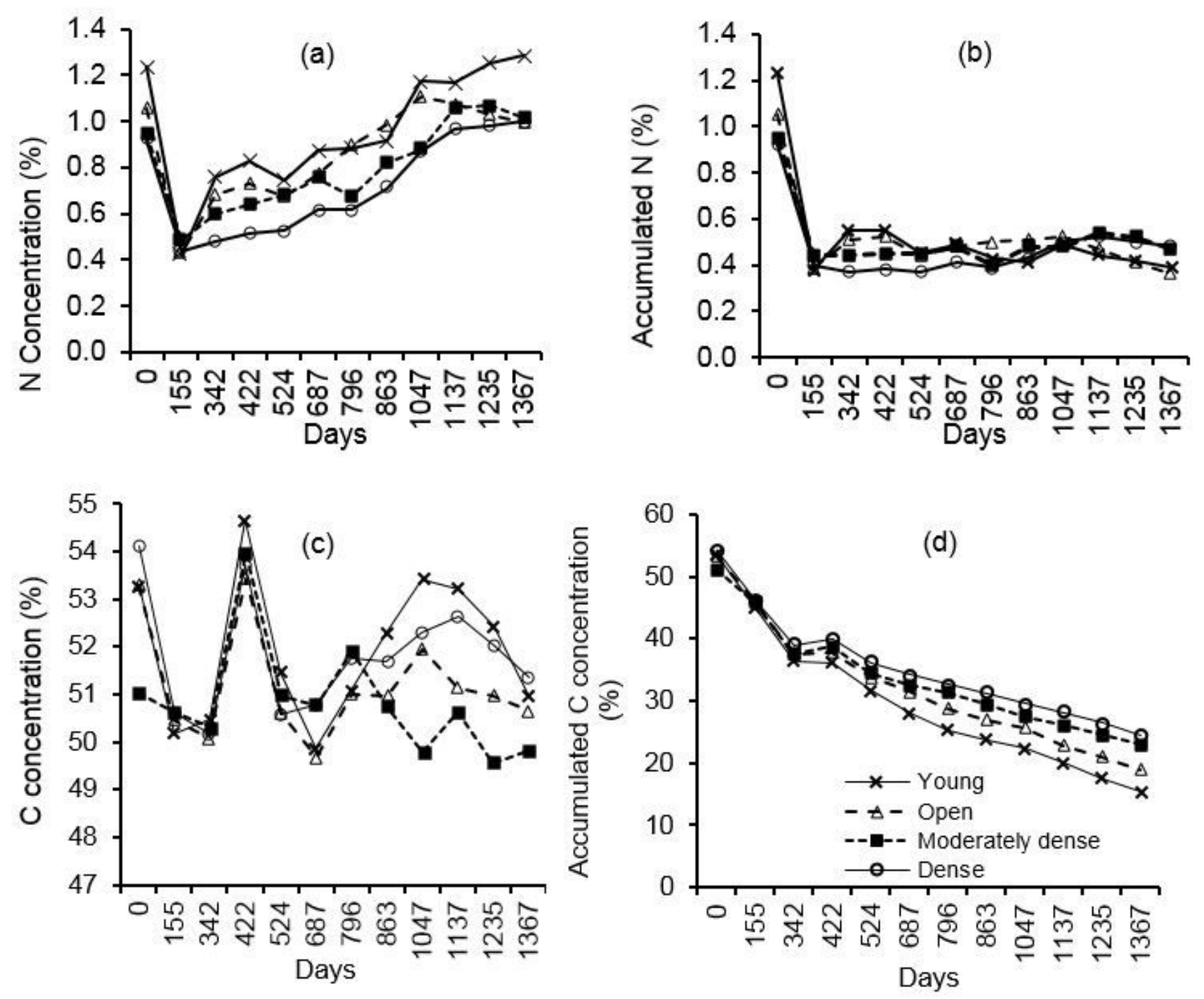

Figure 3

a) $\mathrm{N}$ concentration b) accumulated $\mathrm{N}$ concentration c) $\mathrm{C}$ concentration d) accumulated $\mathrm{C}$ concentration of decomposing litter 


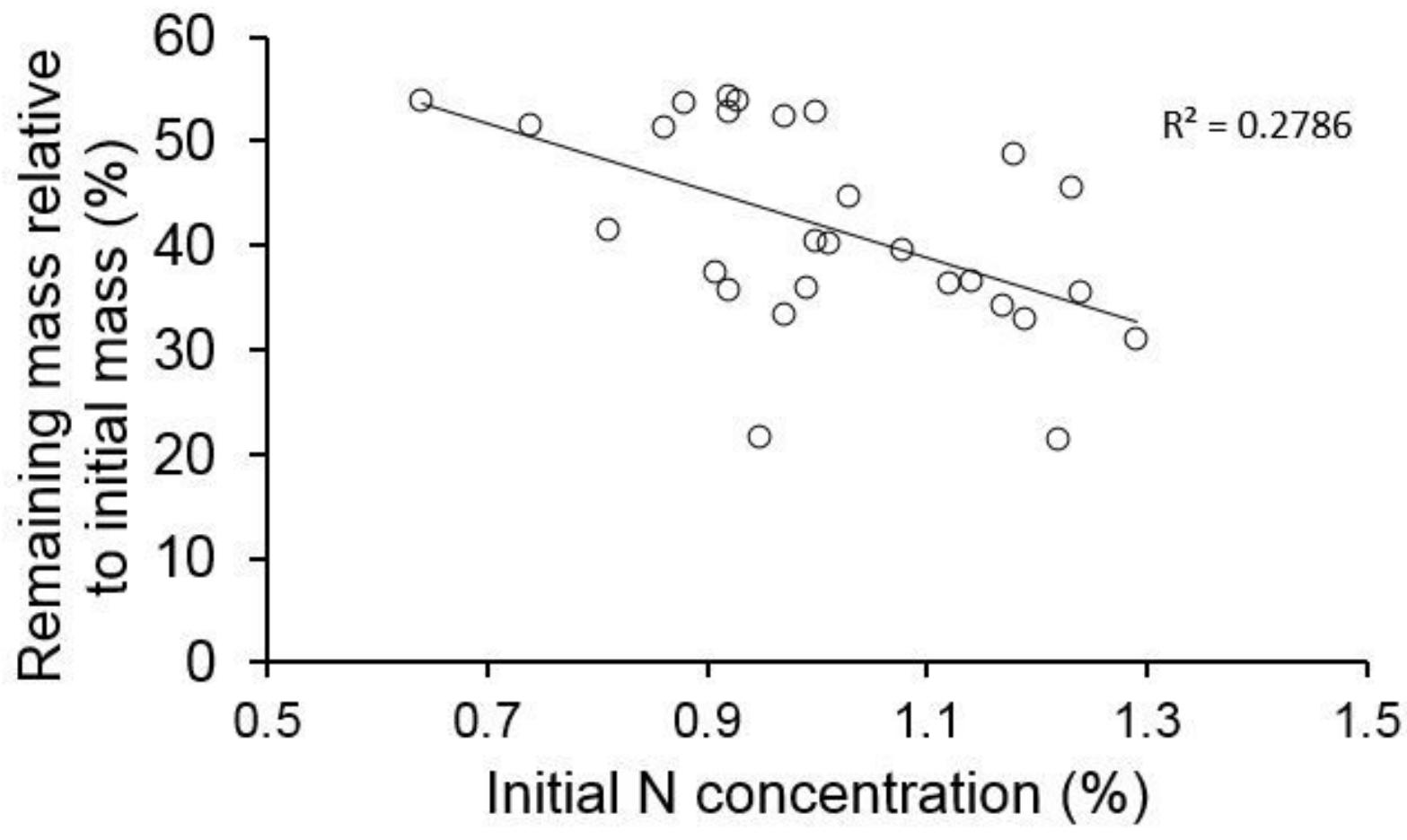

Figure 4

The relationship between remaining mass in April 2016 relative to the initial mass of litter 